九州大学学術情報リポジトリ

Kyushu University Institutional Repository

\title{
CONTRIBUTIONS TO THE TECTONIC HISTORY IN THE OUTER ZONE OF SOUTHWEST JAPAN
}

Matsumoto, Tatsuro

Faculty of Sciences, Kyushu University

Kanmera, Kametoshi

Faculty of Sciences, Kyushu University

https://doi.org/10.5109/1524102

出版情報：九州大學理學部紀要：Series D, Geology. 3 (2)，pp.77-90，1949-11-10. Faculty of Science, Kyushu University

バージョン:

権利関係 : 
Memoirs of the. Faculty of Science, Kyūshū University,

Ser. D, Vol. III; No. 2, 1949

\title{
CONTRIBUTIONS TO THE TECTONIC HISTORY IN THE OUTER ZONE OF SOUTHWEST JAPAN
}

\author{
By \\ Tatsurō Matsumoto \& Kametoshi KÁnMERA
}

(Received April 20th 1949)

\section{Introduction}

The Outer Zone of Southwest Japan and the Kwanto Mountainland consist geotectonically of three major terrains of equatorial trend. They are the northern terrain composed chiefly of the Sanbagawa-Mikabu metamorphic complex, the middle terrain mainly composed of the Paleozoic Chichibu supergroup, and the southern terrain of the Shimantogawa complex, i.e. the undifferentiated Mesozoic and older Tertiary. In the middle Chichibu terrain, there are several areas where fossiliferous Mesozoic formations are distributed in contact with the Paleozoic. They have been called the Mesozoic basins or the Mesozoic valleys, according to their topographic expression. As the area is important to analyse geologic history and geologic structure, various researches have hitherto been done there. Among these "Mesozoic basins", those in Shikoku were repeatedly investigated by many geologists and are still now studied by members of the Geologic Institute of Tōkyō University. On both east and west side of Shikoku, there are two important "Mesozoic valleys", namely the Aritagawa valley (or the Yuasa district) in Wakayama Prefecture, and the lower valley of the Kuma (or the Yatsushiro-Kuma district) in Kumamoto Prefecture. We, at the Geologic Institute of Kyūshū University, are carrying out the research to clear out the stratigraphy and geologic structure of the two districts so as to contribute to the knowledge of the tectonic history of the major zone. The observed facts were partly 
described in the Japanese texts ${ }^{1}$, and, as a report of progress, short papers were read on the Annual Meeting of the Geological Society of Japan ${ }^{2)}$. They are somewhat different or new as compared with the familiar knowledge chiefly derived from the data of central Shikoku by T. Kobayashi ${ }^{3 \text { ) }}$ and others. Although our research is still in progress, we think it necessary and adequate to offer here briefly the obtained notable results concerning the problem, so that we can cooperate with many geologists,--foreign and in our country.4)

\section{Occurrence of the metamorphic group and the Gotlandian formation}

The main part of the area under consideration is, as stated above, occupied by the formations belonging to the Chichibu supergroup of Carboniferous-Permian Period and the late Mesozoic formations. They are arranged in many parallel or nearly parallel belts which are separated by a tectonic line or a narrow tectonic zone. The latter is represented by a group of highly contorted and sheared rocks, thrusts or faults, and is accompanied with various kinds of igneous rocks. The igneous body does not always show a simple intrusive form, but it includes a squeezed out or thrust up mass of older intrusion. (See geologic map and profiles)

In this narrow tectonic zone, we discovered, furthermore, both in the Yuasa district and in the Yatsushiro-Kuma district, metamorphic rocks of various kinds. Among them, we recognize most commonly mica-gneiss and amphibolite (hornblende-plagio-

1) T. Matsumoto, 1947: The geological research of the Aritagawa Valley, Wakayama Pref. (Reports from geol. Inst., Fac. Sci.. Kyūshū Univ., Vol. 2, No. 1); K. KanmarA 1949: The geological research of the Ebirase-Könose district, mid.valley of the Kuma, Kumamoto Pref. (Ibid., vol. 2, no. 2).

2) T. Matsumoto, 1948: A contribution to the tectonic history in the Outer Zone of Southwest Japan (Abstract) (Jour. Geol. Soc. Japan, vol. 53) ; K. Kanmera \& T. Matsumoto, 1949: New geological observations along the lower valley of the Kuma (Abstract) (Ibid., Vol. 54) (both in Japanese).

3) T. Kobayashi, 1941 : The Sakawa Orogenic Cycle and its bearing on the Japanese Islands (Jour. Fac. Sci., Tökyö Univ., Sec. II, vol. 5, pt. 7); T. Kobayashi, A. Fujita \& T. Kimura, 1945: On the geology of the central part of southern Shikoku (Jap. Jour. Geol. \& Gegr., Vol. 20, No. 1).

4) This paper is a part of the results in our work entitled "Geotectonic research on some important areas in Japan." We are indebted much to the Educational Department from which the grant has given to us for the research. 
clase-gneiss). The occurrence of these rocks is noteworthy, because they belong to such kind of rock which is usually considered as a product of high-grade regional metamorphism. They are locally redeformed and changed to phyllonite. Between the gneiss and the non-metamorphosed rocks or at least phyllitic rocks of the undoubtful Chichibu supergroup, there is always a fault-plane. The gradual change from one to the other has never been observed. Although the meaning of the observed facts has not yet been thoroughly interpreted, we are at present inclined to regard the gneisses as a squeezed out core of the older and deep-seated metamorphic complex, which, in turn, is possibly correlated to the Higo gneiss group of middle Kyūshü. $\left.{ }^{5}\right)$

Along one of the tectonic zones crossing the lower valley of the Kuma, we detected a very narrow belt $(100 \mathrm{~m}$. or less in breadth) of the Gotlandian limestone with slaty greenish tuffaceous shale. The limestone is crystalline or subcrystalline, containing fossils of Halysites sp. and other coelenterates, while Lingula sp. is contained in the shale. The Gotlandian formation is best exposed near Fukami, Shimomatsukuma-mura, ${ }^{6)}$ southeast of Yatsushiro City. It is in contact with the above mentioned gneiss on its southern side, and with the lower Paleocretaceous Ryoseki group on its northern side, by a high-angled fault-plane. We regard it also as possibly a squeezed out mass or a dragged out slice of the older complex. ${ }^{7}$ Neverthless, we should note a high contrast of metamorphic grade between the gneiss and the Gotlandian formation.

Another remarkable fact is the discovery of the diaphthoritic (i. e. phyllonitized) piedmontite-quartz-schist at a locality $4 \mathrm{~km}$. southeast of Hinagu, ${ }^{\text {s) }}$ along the same tectonic zone, for the piedmontite-quartz-schist is one of the characteristic members of the Sanbagawa metamorphic group which occupies the northern terrain of the Outer Zone and of the Kwanto Mountainland, and

5) T. Matsumoto: The Higo gneiss-group and its significance in tectonic history (Abstract of papers read before the 56th Annual Meeting of the Geol. Soc. of Japan, 1949).

6) 熊本䇣八代郡下松求麻村澡承

i) We expect that the same interpretation may rule over the recently reported Gotlandian occurrence in Shikoku.

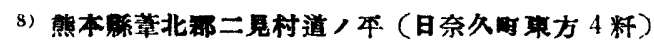


is also found in Middle Kyūshū (the "Nagasaki Dreiecke" of Fr. von. Richthofen). Green phyllites are also detected in the zone. They may be partly a green phyllonite from amphibolite mentioned above and partly the metamorphosed rock related to older diabasic or gabbroic intrusion.

\section{Conglomerate-bearing Permian formation and its signifi- cance in tectonic history}

Although we cannot yet describe completely the stratigraphy and facies of the Chichibu supergroup of the area under consideration, what we must remark here is the recognition of a Permin formation of peculiar facies containing conglomerate. The formation is best exposed at Kukino and Kasamatsu, Kawamatamura, Yatsushiro-gun,9) and is distributed eastnortheastward into Kuriki-Kakisako-mura ${ }^{10)}$ within a belt of three to five kilometers width. Its main part was misidentified by the former investigator as belonging to late Mesozoic (H. Ohtani's Kawamata formation ${ }^{11}$ ), but from fossil evidence-i. e. occurrence of the fusulinids of the Neoschwagerininae and the Verbeekininae-the Permian age is unquestionable.

The formation is considerably thick (more than $1,000 \mathrm{~m}$ ), and consists of shale, conglomerate, sandstone, and the lenticular limestone. As a whole, black shale is predominant. A thin coaly shale and a laminated sandstone or sandy shale with minute carbonaceous flakes are met with. The conglomerate is of fanglomeratic nature, occurrs sporadically at many horizons, shows thickening and thinning out, and passes rapidly to sandstone and shale. It is ill-sorted, consisting of well rounded boulders, cobbles, pebbles and granules. The matrix is sandy and more frequently muddy, and sometimes the shale contains isolated pebbles. The formation does not show such a regular arrangement of stratigraphic sequence as that indicating. a normal cycle of sedimentation. In short, the facies is peculiar when compared with the usual case of the Chichibu supergroup.

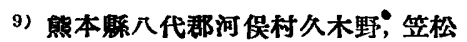

10) 慜本醥八代郡栗木村, 柿迫村

11) H. Ohtani 1926: Stratigraphy and structure of the Yatsushiro district, Kumamoto Pref., Kuma-Kii Mountainland (Jour. Geol. Soc. Japan, Vol. 33) (in Japanese).
} 
The limestone, which is impure, black and sometimes arenaceous, contains fossils of fusulinids, corals, stromatoporoids, crinoids, brachiopods, calcareous algae, etc. The biologic facies is also unfamiliar to the Chichibu supergroup of the Outer Zone.

Another peculiarity is found in the composition of the conglomerate. The boulders, cobbles, and pebbles are those of aplite, leucocratic granite, adamellite, biotite-trondhjemite, biotite-hornblende-granodiorite, tonalite, quartz-diorite, gabbro, diabase, metagabbro, serpentinite, quartz-porphyry, liparite, and andesitic rock. On some case, sandstone, shale, marl and limestone are abundant, which are probably a product of the contemporaneous erosion. The formation is, at present, in contact with the other formations of the Chichibu supergroup on both the northern and southern sides, and with the upper Triassic and late Mesozoic formation in the middle part all by a contorted fault-zone. Although the strata show high-angled dip, the deformation of the rock is weaker than in other Paleozoic rocks, being rather comparable to that of the Triassic strata found near by.

Strata referable to the same formation are distributed between the igneous (or metamorphic) rock, and the marginal part of late Mesozoic formations, forming a very narrow non-metamorphosed Permian belt along a number of tectonic zone. The examples are found at Fukami, and at Kozaki, ${ }^{12}$ ) Shimomatsukuma-mura: they correspond partly to what has been called the Fukami-Paleozoic belt $^{13)}$ and the Kozaki-Paleozoic limestone belt ${ }^{14)}$ respectively.

At a locality from Suhara ${ }^{15}$ to Takada and at a few other localities in the Yuasa district, Wakayama Pref., Matsumoto found the Paleozoic formation containing the conglomerate similar to that in the Yatsushiro-Kuma district. And what is called the Yasuba conglomerate ${ }^{16)}$ in Shikoku and in the Kwanto Mountain-

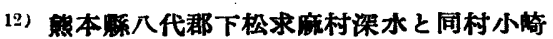

13) H. Ohtani, 1926: op.cit. (深水古生展带)

15) S. Онмасні, 1938: Mesozoic Stratigraphy and Structure of the Yatsushiro district, Kumamoto Pref. (Jour. Geol. Soc. Japan, Vol. 45) (in Japanese) (小㥓石灰岩古生 居费）

15) 和歌山鲧有田郡栖川村栖原から千田村高田に至る中间地点

16) 休堨保岩 T. KinAyashi, 1941 : op. cit. (Postscripts, p. 541). R. ToRIyAma: Studies on the Yasuba Conglomerate and its allies, I-IV (Jap. Jour. Geol. \& Geogr., Vol. 18. no. 4, 1942; vol. 19 , nos. $1-4,1944$; vol. 20 , no. 1,1945 , vol. 20 nos. $2-4,1947$ ). 
land may partly be comparable to the formation under question, although its detailed occurrence is yet questionable.

If these upper Paleozoic formations of peculiar facies are accurately correlated with one another, they should be summarized in one group, to which we would like to propose the name Kuma group. ${ }^{17)}$

It is, furthermore, worthy to remark that the formation under discussion quite resembles the Permian Mizukoshi formation ${ }^{18}$ in central Kyūshū and the middle or upper Permian Toyoma formation containing Usuginu conglomerate ${ }^{19}$ in the Kitakami Mountainland. The similar conglomerate-bearing Permian formation is found at Tsunemori ${ }^{20)}$ of Yamaguchi Pref., and at Maizuru ${ }^{21)}$ of Kyōto Pref., both in the Inner Zone of Southwest Japan.

In conclusion, these formations seem to have the nature of orogenic sedimentation, being the "Mollase-type" deposits during late Paleozoic tectonically mobile period. And especially noteworthy is the point that an orogenic phase of the period have been expressed, by this sort of peculiar sedimentational facies, in various geotectonic provinces within the Japanese Islands, either at western arm and at eastern arm, or on inner side, central part, and outer side. As to the meaning of the igneous rocks found in the pebbles of the conglomerate, Matsumoto has an opinion ${ }^{22}$ that they may have derived from the then eroded external part of the magmatic zone derived from the deeper part of the older Japanese orogenic body.

3. Relation between the Mesozoic formations and the Paleozoic groups

\section{7) 球磨雷群}

18) 水越層: T. Matsumoto \& H. Fujomoto: On a formation of the Chichibu supergroup in Kami-masuki-gun, Kumamoto Pref. (Jour. Geol. Soc. Japan, vol. 46, 1939) (in Japanese with English resume).

19）登米層 (溥衣岩を含む)：M. MinAto：Phasenanalyse der Gebirgebildungen der pelaeozoische Atra im Kitagami Gebirge (Jap. Jour. Geol. \& Geogr., 19, nos. 1-4, 1944).

20) 常森層

21) 等鹤

22) The explanation of the opinion was offered partly at the following occasion. T. Matsumoto \& T. BekкI: Geology of the Ryuhozan district, Kumamoto Pref. (Paper read before the Meeting of Fukuoka Branch of the Geol. Soc. Japan, in Feb. 1949), T. Matsumotu: The Higo gneiss and its significance in tectonic history (Paper read before the 56 th Annual Meeting of the Geol. Soc. Japan, 1949) 
(1) Stratigraphic facts.-At three localities near Yuasa, Wakayama Pref., a distinct unconformity between the Paleozoic and the basal conglomerate of the Paleocretaceous RyosekiMonobegawa group is exposed. The exposure is interpreted to represent the original general relation, which in turn, is, in most other places, modified by later deformation and erosion. On the eastern extension of one of the localities, along the Aritagawa valley, the Neocretaceous Futagawa formation overlaps the Paleocretaceous and lies unconformably on the Paleozoic phyllitic rocks. On the southern side of the Cretaceous field, the basal part of the Upper Monobegawa subgroup (of Upper Paleocretaceous) is in contact with another portion of the Paleozoic.

In the Yatsushiro-Kuma district, the upper Jurassic Torinosu group is, at present, mostly in fault relation to the Paleozoic, but the basal member is often traceable along the boundary, while at a few localities, a distinct unconformity is exposed. When the Mesozoic formation is exposed repeatedly in parallel tectonic belts, the basal part of the formation is in contact with the various different part of the Paleozoic. These feaures again indicate that the distinct unconformity was the original general state and that faults, if present, has developed near the unconformable boundary.

The conglomerate of the Torinosu group, as well as that of the Cretaceous Ryoseki and Monobegawa group contains abundantly pebbles of chert, hornstone, sandstone, slate, schalstein and limestone, all of them probably had derived from the Paleozoic terrain. Furthermore, what is of special interest is the fact that boulders and pebbles of meta-gabbro, meta-diabase, meta-basalt, green phyllite, hematite-guartz -phyllite, black phyllite, etc. are found in the basal part of the Ryoseki group at Takada, $5 \mathrm{~km}$. northwest of Yuasa. These rocks closely resemble those of the so-called Mikabu metamorphic group, which is exposed just in the northern adjacent area.

(2) Structural features.-In both Yuasa and Yatsushiro-Kuma districts, the rocks of the Paleozoic Chichibu supergroup (excluding the Kuma group described in article 2) are somewhat dynamically affected, e. g. changing to slate or phyllite in argillaceous rocks, while the late Mesozoic rocks have not suffered from the same process. Indeed, the late Mesozoic strata show 
intense folding and thrusting, being considerably compressed, but the structure as a whole is of comparatively shallow-type, showing fairly distinct contrast to the deep-seated deformation of Paleozoic strata. The Pseudomonotis (Entomonotis)-bearing upper Triassic strata of the two localities in the Yatsushiro-Kuma district resemble in structural feature rather the Upper Jurassic and Paleocretaceous strata.

(3) A feature in facies.-The late Mesozoic formations are desposits of shallow-water (either marine and paralic) environment where terrigenous matter is more or less rapidly supplied. Conglomerate occurs repeatedly through the stratigraphic sequence, which, in turn, shows a number of cycles of sedimentation. The thickness of each group of formations (or each cycle) is nearly $500 \mathrm{~m}$ or so.

The facies, thus, is the kind of deposition on a "Labile Schelf" where the basement had been considerably consolidated. The feature is again a remarkable contrast to the true geosynclinal facies of the Paleozoic Chichibu supergroup.

(4) Summarizing the above three points of observation, we can lead to the conclusion that before the deposition of the Mesozoic - especially the late Mesozoic formations here presented, the Paleozoic rocks had been considerably folded, deformed, and partly metamorphosed. Thus thé late Paleozoic to early Triassic crustal movement must have been conspicuous in the Outher Zone, at least in its northern half. Our opinion, from many observed facts, is that the parallelism of general trend between the Mesozoic and the Paleozoic strata does not necessarily mean the structural conformity, but rather indicate, in this case, the imitation of the superficial Mesozoic structure to the older fundamental structure of the Paleozoic.

\section{Late Mesozoic tectonically-mobile Period}

The late Mesozoic formations of the districts under consideration are as follows:

Upper Jurassic :

Torinosu group (open sea)

Lower Paleocretaceous :

Ryoseki group (non-marine or paralic)

Middle Paleocretaceous:

in both Yuasa
and Yatsu-
shiro districts 
Lower Monobegawa subgroup (marine)

Upper Paleocretaceous :

Upper Monobegawa subgroup (paralic)

Lower Neocretaceous :

Lower Sotoizumi subgroup

Middle-upper Neocretaceous :

Upper Sotoizumi subgroup

in Yuasa districts

Mid-Cretaceous (?) :

Yatsushiro group-in Yatsushiro district

Each of them represents a minor cycle of sedimentation. At the boundary of the groups or subgroups, we can often observe an abrupt change of sedimentational condition, remarkable difference shown in the materials of coarse-grained deposits, the development of basal conglomerate, and local or provincial ${ }^{23)}$ unconformity, although the strata are in general parallel with one another. And, as has described in the preceding article, each group, in some place, directly overlies the Paleozoic by a distinct unconformity. Judging from these and other features related to stratigraphy and facies, we are inclined to consider these late Mesozoic formations as representing the deposition during the period when the area and the adjacent area were tectonically somewhat mobile.

So far as the present state of our knowledge concerns, the phases of the crustal mobility in late Mesozoic Period seem to be expressed at (1) a certain epoch in late Jurassic, (2) dawn of Cretaceous, (3) early-middle Paleocretaceous, (4) middle-late Paleocretaceous, (5) post-Paleocretaceous, pre-Neocretaceous, and (6) midst of Neocretaceous. Among these phases, the fifth phase has hitherto been said to be most significant, chiefly from the data of central Shikoku, and was called by $\mathrm{T}$. Kobayashi ${ }^{24}$ as the Sakawa Phase. We are inclined to have an opinion that all the phases are important, their expression, however, having been somewhat different in different provinces within the major terrain. The paleogeographic condition changed as time go on, and in a major order the chang became conspicuous towards the later half of late-Mesozoic Period.

23) 'Provincial'. here means wider and conspicuous than 'local' but not of so large scale as 'regional'. The base of the Yatsushiro group in the Yatsushiro-Kuma dis. trict belongs to such kind of unconformity.

24) T. KовAYASH, 1941 : op. cit. 
Comparing with the late Mesozoic geologic history of the Inner Zone of Southwest Japan and Northeast Japan, on which Matsumoto ${ }^{25}$ ) discussed on another occasion, the late Mesozoic as a whole, is in Japan a tectonically mobile period, although the the difference in expression of crustal movements among the major geotectonic units is fairly conspicuous. In strong contrast to the Inner Side and Northeast Japan, the late Mesozoic igneous activity is very slight in the Outer Zone. Only a thin fine-grained tuffaceous shale is intercalated in some of the Lower Monobegawa ${ }^{26)}$, Yatsushiro, and Sotoizumi groups. (see also article 6)

\section{Post-Cretaceous movements}

Strata of the late Mesozoic formations mentioned above are intensely folded and thrusted, forming in major scale an asymmetric synclinorium or a structural basin, which includes a number of folds and thrust-sheets. The deformation may in certain degree depend on the late Mesozoic crustal movements but the evidence of post-Cretaceous movements is not deniable.

As the younger representative of the Mesozoic formations, we should note on two groups, namely, the Sotoizumi group (includirfg the Matsubara, the Futagawa and the Toyajo formations) of the Aritagawa Valley and the Yatsushiro group of the Yatsushiro-Kuma district. The former, which is exposed along the valley forms two synclinoria that have partly the overturned wing and are accompanied by high-angled thrusts. The deformation of this Neocretaceous group is almost as intense as that shown in the Paleocretaceous one, and strata belonging to both the Paleocretaceous and the Neocretaceaus form one and the same folding at least partly, only the bottom of a syncline at Toyajo Mountain being relatively gentle.

The Yatsushiro group which resembles in rock-facies the Mifune group of middle Kyüshu, is exposed in the mountainous part of the Yatsushiro-Kuma district, showing a folding some-

25) T. Matsumoto, 1949: The late Mesozoic geologic history in the Nagato Province, Southwest Japan (Japanese Jour. Geol. and Geogr., vol. 21).

26) In the Ebirase-Kōnōse area, crossing middle valley of the Kuma, the similar tuffaceous shale is found in the so-called Torinosu group. We say of "the so-called Torinosu group," because it may possibly belong either to a different facies of the Monobegawa group or to the true Torinosu group. 
what more gentle than the unconformably underlying formation of Paleocretaceous proper. But the deformation is as moderate as that observed in the Mifune group of central Kyūshū, and a few thrusts and faults cut the group.

During the post-Cretaceous crustal movements, probably the basement (composed of already folded Paleozoic) may have been deformed rather in blockwise manner or en block (i.e. Schollenversiebung und Schollenüberschiebung), while the superjacent Mesozoic formation may have shown folding plus faulting (including high-angled thrusting) (i.e. Bruchfaltung).

As the Tertiary formation is not developed in the district under consideration, it is hard to decide directly the exact date of the post-Cretaceous movements. Judging, however, from the recent data $^{27}$ obtained from the adjacent two tectonic units, middle Kyūshū and the outer side of the Outer Zone, we are inclined to attach sufficient importance to the two orogenic phases, namely, the post-Cretaceous-earliest Tertiary epoch and the late Paleogene-early Neogene epoch.

Fault systems of NW, NNE and NS trends, which cut frequently the older structure of the equatorial trend, and some reworked equatorial faults are probably of further later date.

Thus the constitution of the complicated and characteristic structure of the Outer Zone depends much on the post-Cretaceous and Tertiary crustal movements, as well as on the late Mesozoic and late-Paleozoic-early Traiassic movements.

\section{Note on igneous activity}

As has already mentioned, various kinds of igneous rocks occur along the narrow thrust zone of the districts under consideration. The corresponding igneous rocks in central Shikoku is called the Yokokurayama Igneous group. ${ }^{28}$ ) The current view regards them as the product of syntectonic intrusion at the midCretaceous "Sakawa-phase." Our analytical research, however, are preșenting somewhat different idea. As the petrological study has not yet been completed, a few notes should be here described.

(2) Especially the data concerning the structural and stratigraphic relation between the Neocretaceous and Paleogene Tertiary in the Amakusa Islands, and that between the Paleogene and the Neogene in Miyazaki, Wakayama and Shizuoka Prefectures.

28) T. KOBAYASH 1941 , op. cit. p. 383 , p. 416. 
Fig. 1 Geological map of the Yatsushiro-Kuma district, Kumamoto Pr e fecture.

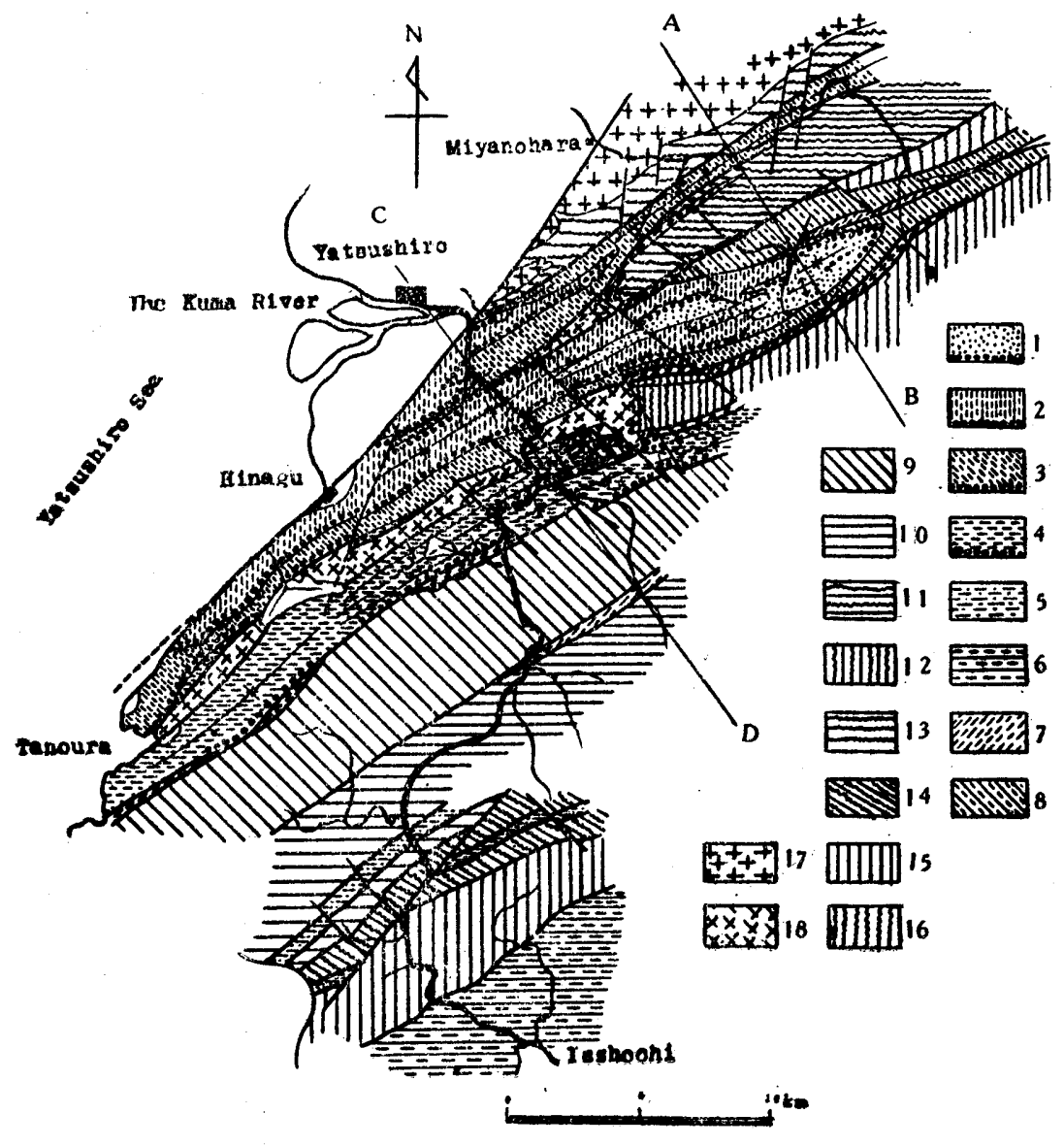

Fig. 2 Geological profiles of the Kuma-Yatsushiro district, Kumamoto Pref.
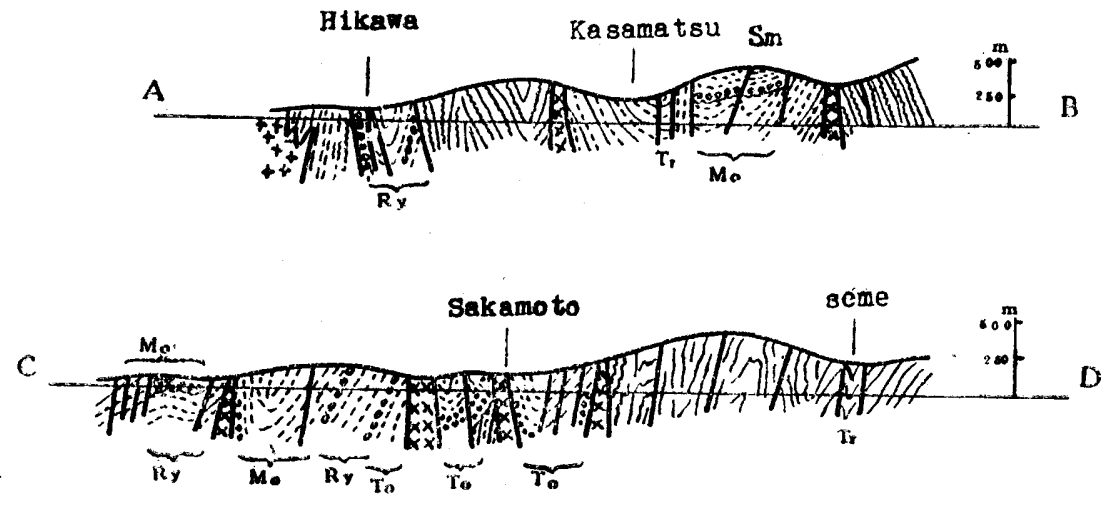
Fig. 1

1. Yatsushiro group (Sm) (Mid-Cretaceous?)

2. Monobegawa group (Mo) Middle Paleocretaceous)

3. Ryoseki group (Ry) (Lower Paleocretaceous)

4. Torinosu group (To) (Upper Jurassic)

5. So-called Torinosu group of Ebirase

6. Shimantogawa Complex (Undifferenciated Mesozoic)

7. Upper Triassic (Tr)

8. Kuma group (Permian)

9. Yonaku formation (Permian)

10. Yoshiwo formation

11. Odawo formation

12. Hashirimizu formation

13. Ryuhozan group

Chichibu supergroup (mainly Upper Paleozoic)

14. North-Kōnose formation

15. South-Könose formation

16. Lower Carboniferous of Kakisako

17. Miyanohara tonalites

18. Igneous and metamorphic rocks along the thrust-zone

(1) Some of the granitic rocks associated with the gneiss group (described in article 1) may be intimately related to the older or deep-seated gneissification.

(2) Deformed serpentinite is very common in the igneous belt. It is sometimes intruded into the phyllitic rocks of the Paleozoic. The belt contains gneissose hornblende-gabbroid rock, (which has granular texture and sometimes garnetiferous) and the associated hornblendite. The rock has sometimes suffered from retrogressive mineralogical alteration and cataclastic effect. Small masses of granodiorite (containing basic patches) and dikes of leucocratic granite and aplite seem to be later than the gabbro, and has also been cataclastically deformed, having been affected from chloritization, prehnitization, etc. Some of the aplite-pegmatite dike cuts through the Permian Paleozoic strata. Aphanitic and very compact "Haelleflinta" and quartz-keratophyre-like rock are, furthermore, met with, and they also cut through the Paleozoic as dikes and lenticular small pockets.

Concerning petrogenesis and intrusive or metamorphic history of these rocks, we leave much to be studied in future. And especially ambiguous is the meaning of the amphibole-eclogite-like rock and epidioritic rock which occur as a small lenticular mass in the serpentinite body. 
(3) We have not yet seen the exposure where any of the above-mentioned rocks is clearly cutting through the Mesozoic formation. ${ }^{29}$ When the two are in contact, they are always in fault-relation. On the other hand, diabasic and basaltic dikes or veins cut through the Mesozoic strata as well as the preceding older igneous and metamorphic rocks. (Therefore, there are two diabasic rocks of different age.) The alteration including silicification, chloritization, carbonitization and other mineralization affects igneous rock and the adjacent strata. The rock at the fault zone is sometimes fractured, sheared, and cataclastically modified.

Reworking of the older igneous rocks, i. e. their thrusting up or squeezing out may have been common during the folding and thrusting of the Mesozoic strata, and the feature may have been misidentified as a syntectonic intrusion. The plastically deformed serpentinite must have played an important rule in this squeezing out process. Cataclastic process and the hydrothermal alteation may be mainly the feature of this epoch.

(4) Dikes of aphanitic quartz-porphyrite and then mica-andesite, hornblende-mica-andessite, bronzite-andesite, etc. are sometimes found along the fault, but they are not affected by cataclastic process. They are probably of newer date, i. e. Neogene.

Outside of the "Mesozoic basins," in the more mountainous part of the same Kuma-Kii terrain, granite, granite-porphyry and quartz-porphyry occur as bosses, ring-dikes and other small masses of shallow type. The mass obliquely cuts the general equatorial structural trend of the Outer Zone. This igneous activity is, therefore, post tectonic. And relying upon our judgement as to the date of the crutal movements described in article 5, the activity is of considerably young date, presumably towards mid-Tertiary.

Finally we are greatly indebted to the late Dr. Kenichi Sugi, who gave us valuable aid in the study of igneous and metamorphic rocks.

29) The Permian stratia of the Kuma group (mentioned in article 2) are sometimes intruded by aplite-dike. 